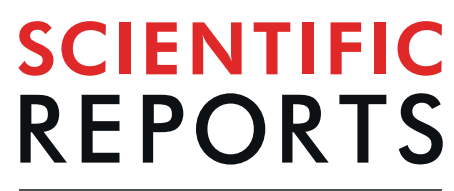

natureresearch

\title{
Electrochemical Degradation of Reactive Black 5 using two- different reactor configuration
}

\author{
Tamara Droguett ${ }^{3}$, Julia Mora-Gómez ${ }^{1}$, Montserrat García-Gabaldón ${ }^{1 *}$, Emma Ortega ${ }^{1}$, \\ Sergio Mestre ${ }^{2}$, Gerardo Cifuentes ${ }^{3} \&$ Valentín Pérez-Herranz $^{1}$
}

\begin{abstract}
Novel Sb-doped $\mathrm{SnO}_{2}$ ceramic electrodes sintered at different temperatures, are applied to the degradation of Reactive Black 5 in both divided and undivided electrochemical reactors. In the undivided reactor the discoloration of the solution took place via the oxidation of RB5 dye, without the corresponding reduction in the chemical oxygen demand for the ceramic electrodes. However, in the divided one, it was possible to achieve the discoloration of the solution while at the same time decreasing the chemical oxygen demand through the $\cdot \mathrm{OH}$-mediated oxidation, although the chemical oxygen demand degradation took place at a slower rate.
\end{abstract}

Azo dyes are widely employed in textile manufacture, which is one of the most polluting sectors within the different human activities. A considerable amount of the dye (between 1-15\%) is discharged into wastewaters after the dyeing process ${ }^{1}$. Reactive Black 5 (RB5), is considered the best option for cotton and other cellulose fibers ${ }^{2}$, and consequently, is the azo dye with the largest consumption rate ${ }^{2}$.

The release of colored wastes is not only an aesthetical aspect, but also avoids the penetration of light, which affects the biological processes. Moreover, many dyes are susceptible of generating toxicity in the aquatic organisms as well as in humans ${ }^{3}$. In addition, the aromatic structures of these chemicals are very refractory and, therefore, resistant to be degraded in wastewater treatment plants since they remain unaffected towards sunlight, oxidizing agents and microorganisms ${ }^{4}$.

The elimination and degradation of RB5 has been reported in the scientific literature using membrane separation techniques ${ }^{5-7}$, electrocoagulation ${ }^{2,8}$, photocatalysis $^{9-11}$, biodegradation ${ }^{12,13}$, advanced oxidation processes ${ }^{14,15}$, electrochemical reduction and oxidation ${ }^{16-18}$ or combined methods ${ }^{19-21}$. Membrane processes, electrocoagulation, direct precipitation or adsorption, just change the contamination from one phase to another. Chemical oxidation using agents such as chlorine produces organochlorine compounds considered very toxic. Photooxidation needs the addition of chemicals, and causes a secondary pollution. The biological degradation is less effective than other methods because of the inhibition of the bacterial activity due to the toxicity of dye ${ }^{22}$.

Electrochemical methods are able of mineralizing the dyes without the addition of chemicals. Besides this advantage, they can be coupled to sources of renewable energy with the aim of decreasing the operational $\operatorname{costs}^{23,24}$. The electrochemical oxidation mainly operates in two different pathways. In the direct oxidation, the contaminant is directly oxidized on the anodic surface; whilst in the indirect oxidation, the transfer of electrons is mediated by oxidant species ${ }^{25}$ such as the hydroxil radicals. The named "active" anodes present low oxygen evolution overpotential ( $\mathrm{Pt}, \mathrm{IrO}_{2}$ and $\mathrm{RuO}_{2}$ ) and possess chemisorbed $\cdot \mathrm{OH}$ radicals, only permitting the partial oxidation of the organic matter. On the contrary, "nonactive" anodes with high oxygen evolution overpotential produce physisorbed $\cdot \mathrm{OH}$ radicals favoring complete mineralization ${ }^{26}$. One of the most widely used anode for the electrochemical degradation of pollutants is the BDD, which has the highest overpotential for oxygen evolution $^{27-29}$. However, these anodes are expensive and their manufacture is complicated, due to the difficulty of finding cheaper materials for the deposition of the diamond layer ${ }^{30}$.

$\mathrm{Sb}$-doped $\mathrm{SnO}_{2}$ anodes, which possess a medium to high oxidation power with an oxygen evolution potential of about $1.9 \mathrm{~V}$ vs. $\mathrm{SHE}^{26}$, have resulted to be highly effective for the electrooxidation of organics ${ }^{31-37}$. Another advantages associated to these electrodes are their fabrication easiness and low cost. However, their major

${ }^{1}$ IEC Group, ISIRYM, Universitat Politècnica de València, Camí de Vera s/n, 46022, València, P.O. Box 22012, E-46071, Spain. ${ }^{2}$ Instituto Universitario de Tecnología Cerámica, Universitat Jaume I, Castellón, Spain. ${ }^{3}$ Depto. de Ingeniería Metalúrgica, Facultad de Ingeniería, Universidad de Santiago de Chile (USACH), Santiago de Chile, Chile. *email: mongarga@iqn.upv.es 
<smiles>Nc1cc2cc(S(=O)(=O)O[Na])c(N=Nc3ccc(S(=O)(=O)CCOS(=O)(=O)O[Na])cc3)c(O)c2c(N)c1N=Nc1ccc(S(=O)(=O)CCOS(=O)(=O)O[Na])cc1</smiles>

Figure 1. Structure of Reactive Black 5 (C.I. No. 20505; M.W. =991.8).

drawback is their low stability when employed as anodes ${ }^{38}$. This is why its use as a massive electrode is not common and $\mathrm{SnO}_{2}$ is normally used as a coating on a metal substrate.

On the hand, ceramic electrodes are being of great importance, as an example is their use in fuel cells working at high temperature, molten salt processes ${ }^{39,40}$, and in electrochemical wastewater treatment ${ }^{41-44}$. Ceramic materials are in their most stable, completely oxidized form, and therefore, unlikely to be further oxidized. Moreover, because of their porous structure, they present a large specific surface area, providing active sites for pollutants adsorption and reaction ${ }^{45}$. Microporous ceramic electrodes could also be used as a reactive membrane to filter the foulants, while acting as an effective electrode to destroy organic foulants, integrating physical separation with electrochemical oxidation.

In a previous study ${ }^{46}$, new microporous $\mathrm{Sb}$-doped $\mathrm{SnO}_{2}$ ceramic electrodes at different sintering temperatures were tested to be used as anodes in electrochemical degradation processes. It was found that the sintered electrode at the lowest temperature $\left(1050^{\circ} \mathrm{C}\right)$ presented a greater potential for oxygen discharge, this value being higher than the Pt electrode (active anode) but lower than the BDD (nonactive anode). In addition, electro-oxidation tests of Norfloxacin (NOR), a widely used antibiotic, were carried out with these electrodes in galvanostatic and potentiostatic mode. The results obtained in terms of degradation and mineralization were satisfactory. In another study ${ }^{47}$, the influence of the reactor configuration (divided and undivided) was studied, and the authors showed that in the divided reactor the degradation of the organic compound was greater than in the undivided one, mainly due to the fact that the membrane prevented the intermediate products formed during the NOR oxidation process from being reduced on the cathode.

The aim of the present work is to corroborate the results obtained previously with these microporous Sb-doped $\mathrm{SnO}_{2}$ ceramic electrodes, verifying their versatility for treating different organic compounds, specifically the RB5 dye, in an undivided and a divided electrochemical cell. In addition, to ensure the electrochemical stability of these electrodes, accelerated life tests under high current density conditions were conducted.

\section{Methods}

Electrodes characterization and service life tests. The manufacture of the $\mathrm{Sb}$-doped $\mathrm{SnO}_{2}$ ceramic electrodes sintered at different temperatures $\left(1050^{\circ} \mathrm{C}, 1150^{\circ} \mathrm{C}\right.$ and $\left.1250^{\circ} \mathrm{C}\right)$ is fully described in detail previously ${ }^{46,47}$. With respect to the accelerated life tests, they consist in the application of a constant current density $\left(100 \mathrm{~mA} \cdot \mathrm{cm}^{-2}\right)$ during $24 \mathrm{~h}$ in a $0.5 \mathrm{M} \mathrm{H}_{2} \mathrm{SO}_{4}$ solution. The working electrode was the ceramic electrode under study, in the presence of $\mathrm{Pt}$ as counter electrode, and $\mathrm{Ag} / \mathrm{AgCl}$ as reference electrode.

The potential of the working electrode is periodically monitored, and the electrode is considered deactivated when its potential increases $5 \mathrm{~V}$ from its initial value ${ }^{48,49}$. If the potential of the working electrode did not change after this period of time, the applied current density was increased by $100 \mathrm{~mA} \cdot \mathrm{cm}^{-2}$ and the cycle was repeated several times.

Electrolysis experiments. The experimental arrangement of both the divided and undivided reactors was previously described in detail ${ }^{47}$. The anode was either a ceramic electrode or a Boron-doped diamond (BDD) electrode (from NeoCoat SA, Switzerland), which is a well-studied anode. Electrolyses experiments were carried out galvanostatically with an Autolab PGSTAT302N potentiostat/galvanostat at applied current values between 5 and $15 \mathrm{~mA} \cdot \mathrm{cm}^{-2}$.

RB5, whose structure is given in Fig. 1, was purchased from Sigma-Aldrich and $\mathrm{Na}_{2} \mathrm{SO}_{4}$ was used as supporting electrolyte (from Panreac). Solutions of $100 \mathrm{mg} \cdot \mathrm{L}^{-1}$ of $\mathrm{RB} 5$ and $0.1 \mathrm{~mol} \cdot \mathrm{L}^{-1}$ of $\mathrm{Na}_{2} \mathrm{SO}_{4}$ were tested in both type of reactors. All experiments were performed under stirring and at room temperature during 5 hours.

Analytical measurements. Every 30 min samples were extracted from the electrochemical reactor, and different operation parameters such as current density or cell voltage were monitored. The discoloration rate and the chemical oxygen demand were measured from every extracted sample. UV-visible spectra were analyzed between 200 and $800 \mathrm{~nm}$ using a Unicam UV4-200 UV/VIS Spectrometer. The mineralization of the dye was measured 


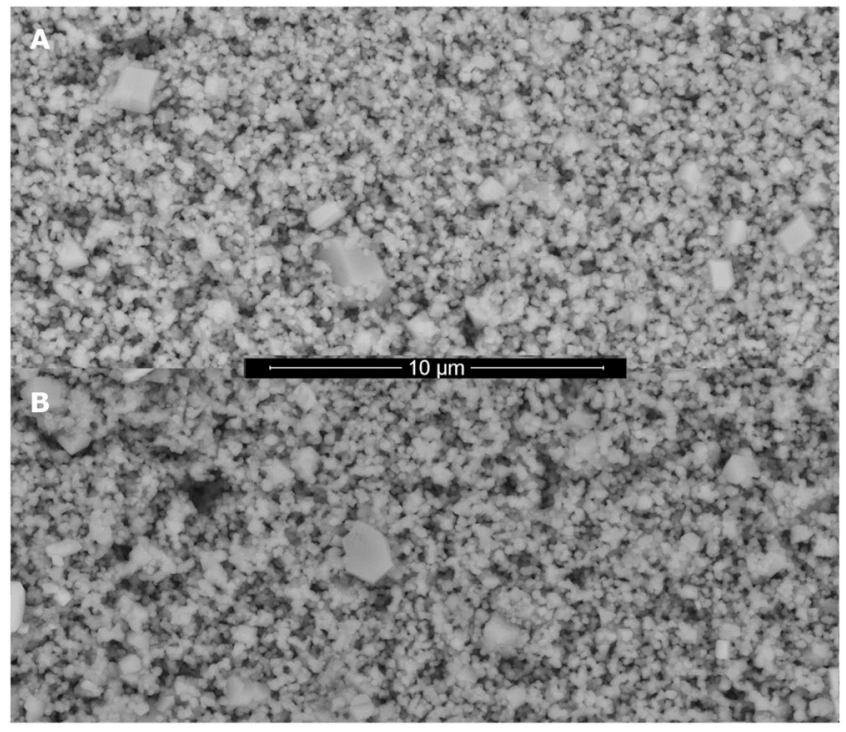

Figure 2. SEM images of the as-prepared ceramic electrode sintered at $1050{ }^{\circ} \mathrm{C}(\mathbf{A})$ and after the service life tests (B).

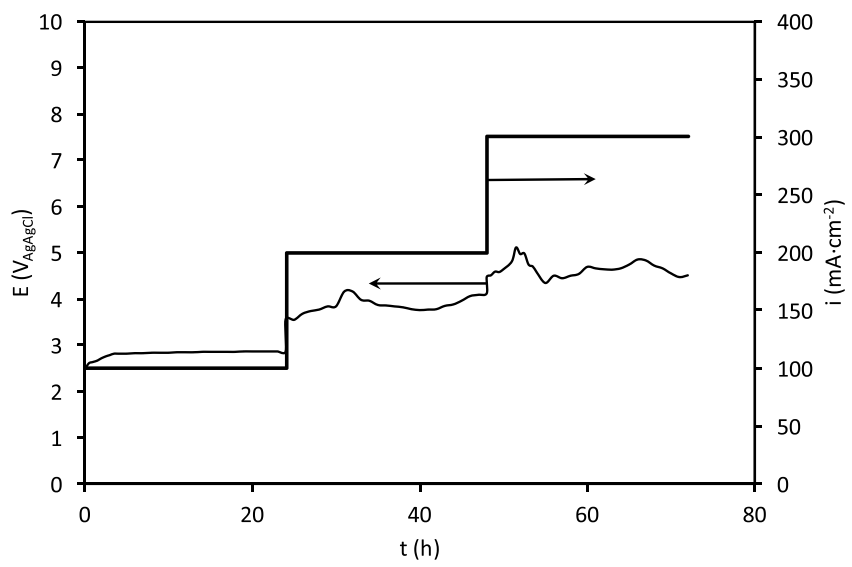

Figure 3. Accelerated service life test of the ceramic electrode sintered at $1050^{\circ} \mathrm{C}$ in $0.5 \mathrm{M} \mathrm{H}_{2} \mathrm{SO}_{4}$.

from the diminution of the chemical oxygen demand (COD) of every sample as a function of time, determined using the dichromate method.

The discoloration of the RB5 solutions was measured from the relative absorbance decrease at $595 \mathrm{~nm}$, which is the maximum visible wavelength $\left(\lambda_{\max }\right)$, according to the following expression ${ }^{50}$ :

$$
\text { Relative absorbance }=\frac{A b s_{t}}{A b s_{0}}
$$

where $\mathrm{Abs}_{\mathrm{t}}$ is the absorbance for a given time $\mathrm{t}$, and $\mathrm{Abs}_{0}$ is the initial absorbance value.

The current efficiency $(\phi)$ of the RB5 oxidation process was estimated from the expression ${ }^{26}$ :

$$
\phi=F V\left(\frac{C O D_{0}-C O D_{t}}{8 \int_{0}^{t} I(t) d t}\right)
$$

where $\mathrm{COD}_{0}$ is the initial chemical oxygen demand and $\mathrm{COD}_{t}$ is the same parameter for a given time $t$, I the current applied, $\mathrm{F}$ the constant of Faraday and V is the volume of the reactor.

\section{Results and Discussion}

Service life tests. In Fig. 2, SEM images of the as-prepared ceramic electrode sintered at $1050^{\circ} \mathrm{C}(\mathrm{A})$ and after the service life tests (B) are shown, while Fig. 3 illustrates the accelerated service life test of the ceramic electrode sintered at $1050^{\circ} \mathrm{C}$ in $0.5 \mathrm{M} \mathrm{H}_{2} \mathrm{SO}_{4}$. At the imposed applied current densities, the oxygen evolution 


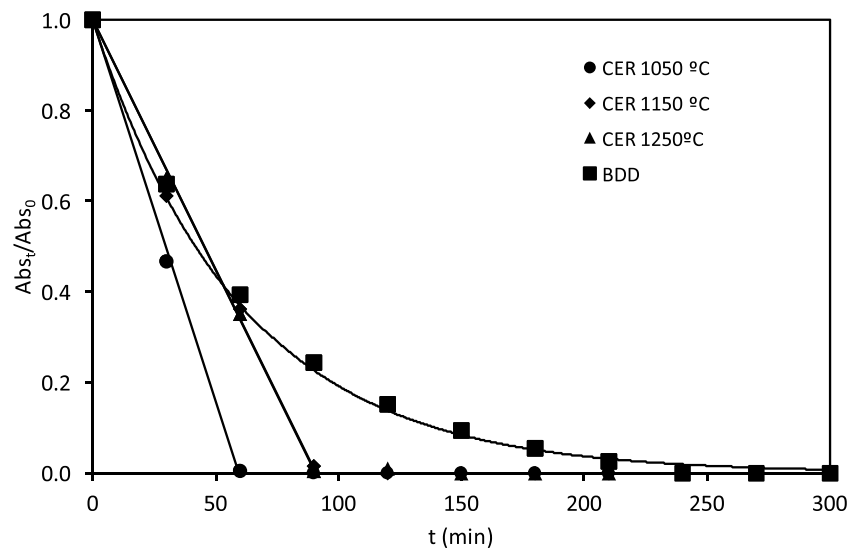

Figure 4. Evolution of the relative absorbance (at $595 \mathrm{~nm}$ ) with the electrolysis time for the electrochemical degradation of RB5 with the ceramic electrodes sintered at different temperatures and the BDD electrode in the undivided reactor.

was the only reaction that takes place, and the gas evolution was observed. There were no visible changes in the electrode throughout the experiment as was confirmed by SEM images. In fact, the electrode retains the structure of the freshly prepared one as can be seen in Fig. 2(B). Overall, it is clear that the electrolysis performed in the conditions of Fig. 3 did not cause any significant damage on the electrode. In fact, the electrode was subsequently reused for another electrolysis experiments.

Figure 3 shows the evolution of the electrode potential during this service life test. When the electrolysis was commenced at an applied current density (i) of $100 \mathrm{~mA} \cdot \mathrm{cm}^{-2}$, the initial electrode potential was about $2.5 \mathrm{~V}$ but within the three first hours it slowly increased to $2.85 \mathrm{~V}$ and thereafter remained almost constant. After 24 hours of electrolysis, i rose up to $200 \mathrm{~mA} \cdot \mathrm{cm}^{-2}$. At this applied current density, the electrode potential took an initial value of $3.5 \mathrm{~V}$, and then it increased slowly with time until reaching an average value of about 3.8 volts. Under these conditions the electrode potential oscillated around this average value, and reached a maximum value of $4.1 \mathrm{~V}$ in the sixth hour. When i increased up to $300 \mathrm{~mA} \cdot \mathrm{cm}^{-2}$, the electrode potential oscillated around $4.5 \mathrm{~V}$ during the 24 hours of electrolysis. In this case, the potential oscillations were greater than for $200 \mathrm{~mA} \cdot \mathrm{cm}^{-2}$, and several potential peaks of approximately $5 \mathrm{~V}$ were observed. These potential peaks observed for i values of 200 and $300 \mathrm{~mA} \cdot \mathrm{cm}^{-2}$ are associated with the formation of oxygen bubbles that block the electrode surface and cause an increase in the electrode potential. When the bubbles leave the electrode surface, the potential returns to its initial value. This phenomenon occurs more often at higher applied current densities. Similar results were obtained for the electrodes sintered at the other temperatures (not shown).

Different results regarding with the service life of $\mathrm{SnO}_{2}$ - $\mathrm{Sb}$ based anodes are found in the literature. A service life value of about $12 \mathrm{~h}$ for Ti/SnO $\mathrm{Sn}_{2}-\mathrm{Sb}_{2} \mathrm{O}_{5}$ anodes was obtained at $100 \mathrm{~mA} \cdot \mathrm{cm}^{-2}$ in $1 \mathrm{M} \mathrm{H}_{2} \mathrm{SO}_{4}{ }^{51}$, while other works reported no change over 48 days for the same type of anodes ${ }^{38}$. On the other hand, service lifetime greater than 30 days for $\mathrm{Ti} / \mathrm{SnO}_{2}-\mathrm{Sb}_{2} \mathrm{O}_{5}$ was obtained by other authors ${ }^{52}$, whilst lower values of service lifetime from $6.4 \mathrm{~h}$ to $42 \mathrm{~h}$ for the same anodes were also reported ${ }^{53}$. Another study found only $10 \mathrm{~min}$ for $\mathrm{Ti} / \mathrm{SnO}_{2}-\mathrm{Sb}_{2} \mathrm{O}_{5}$ anodes ${ }^{54}$, and Chen and Nigro ${ }^{55}$ reported values from 0.68 to 60 hours depending on the substrate. These large variations in the service lifetime reported in the literature may be related to the method of preparing the electrodes.

Hence, taking into consideration the results obtained by the lifetime service tests and considering that no change was observed in the microstructure of the different electrodes tested, it is inferred that the $\mathrm{Sb}-\mathrm{SnO}_{2}$ ceramic electrodes under study are a good alternative to conventional $\mathrm{SnO}_{2}$ electrodes.

Electrolysis experiments. Undivided reactor. Figure 4 presents the relative absorbance measured at $595 \mathrm{~nm}$ (where a maximum absorbance is obtained) over time in the undivided reactor, for the ceramic electrodes sintered at different temperatures and at $15 \mathrm{~mA} \cdot \mathrm{cm}^{-2}$. The results are compared with those obtained with the BDD electrode at the same i value. The electrochemical degradation of RB5 using either the ceramic or the BDD electrodes led to discoloration of the solution as the electrolysis progressed. However, the discoloration kinetics was different depending on the electrode. With the ceramic electrodes, a rapid discoloration of the solution was achieved in less than 90 minutes and in this period, the relative absorbance decreased linearly with time until complete discoloration. In contrast, the discoloration of the solution with the BDD electrode was slower, and the relative absorbance decreased exponentially with time, showing a first order discoloration kinetics.

Different reasons could justify the differences in discoloration observed between both types of electrodes. On one hand, the surface structure of the ceramic electrodes is different from that of the BDD one. Thus, for the same geometric surface area, the ceramic electrodes present a larger specific surface area due to their microporous structure. This causes that for the same applied current density, the electrode potential reached with the ceramic electrodes is less anodic than that reached with the BDD electrode. In fact, for the same value of i $\left(15 \mathrm{~mA} \cdot \mathrm{cm}^{-2}\right)$, the average electrode potential values obtained with each electrode were $2.4 \mathrm{~V}$ for the ceramic electrode sintered at $1050^{\circ} \mathrm{C}, 2.6 \mathrm{~V}$ for those sintered at 1150 and $1250^{\circ} \mathrm{C}$ and $3 \mathrm{~V}$ for the BDD electrode. Therefore, higher discoloration efficiency should be achieved with the ceramic electrode sintered at $1050^{\circ} \mathrm{C}$. 


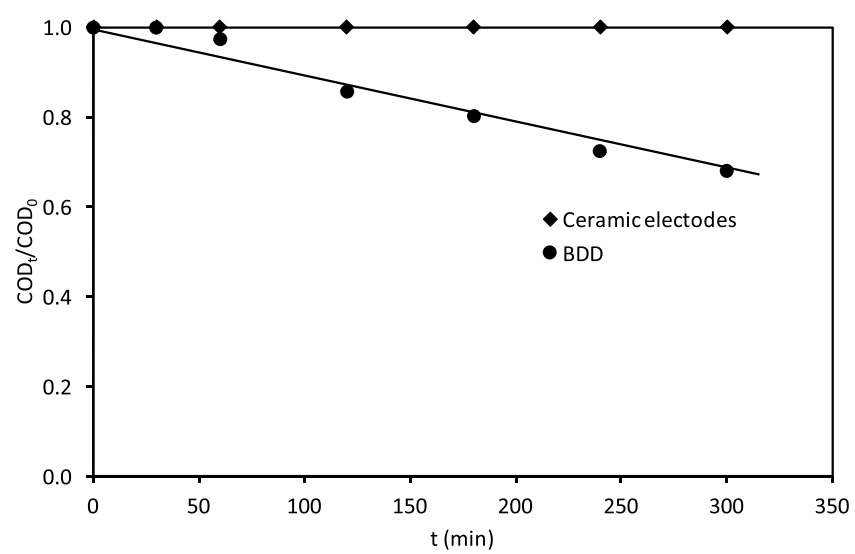

Figure 5. Evolution of the relative COD removal with the electrolysis time for the ceramic electrodes sintered at different temperatures and the BDD electrode in the undivided reactor.
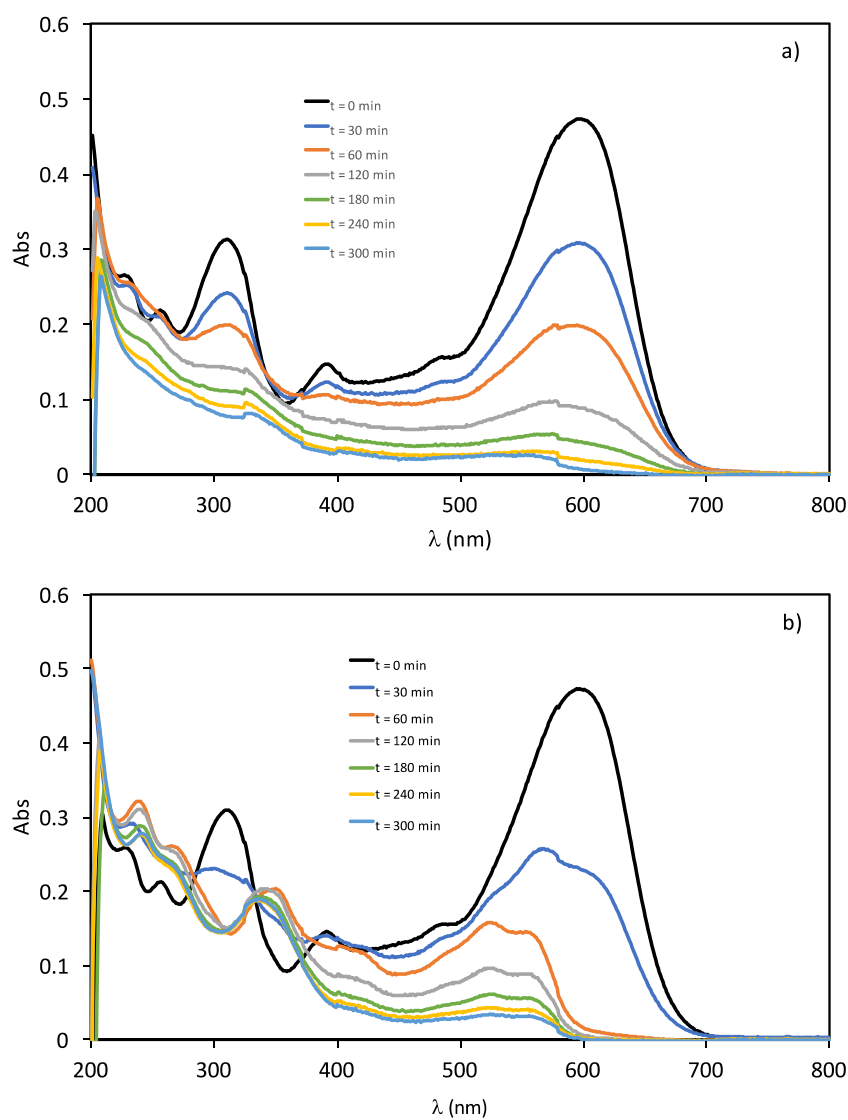

Figure 6. Variation of the UV-visible spectra of a $100 \mathrm{mg} \cdot \mathrm{L}^{-1} \mathrm{RB} 5$ solution with the electrolysis time in an undivided reactor. a) BDD electrode. b) ceramic electrode sintered at $1050{ }^{\circ} \mathrm{C}$.

Comparing these results with those obtained previously for the removal of NOR with the same electrodes ${ }^{46}$, it is observed that using the ceramic electrode of the lowest sintering temperature $\left(1050^{\circ} \mathrm{C}\right)$ the removal of both compounds (NOR and RB5) is greater. This fact is because this electrode presents the highest potential for the oxygen discharge.

Figure 5 shows the COD versus the electrolysis time for the ceramic and the BDD electrodes. A maximum COD decrease of $35 \%$ is achieved after 5 hours of electrolysis with the BDD electrode, whereas for the same electrolysis time, there was no decrease of the COD with the ceramic ones. This low efficiency in COD removal may be due to the formation of different intermediates of the RB5 dye, which are not subsequently mineralized. Some of these intermediates are quite stable and may be more toxic than the original dye $e^{56,57}$. During the degradation of the RB5, the aromatic ring structure can be one of the intermediates. 


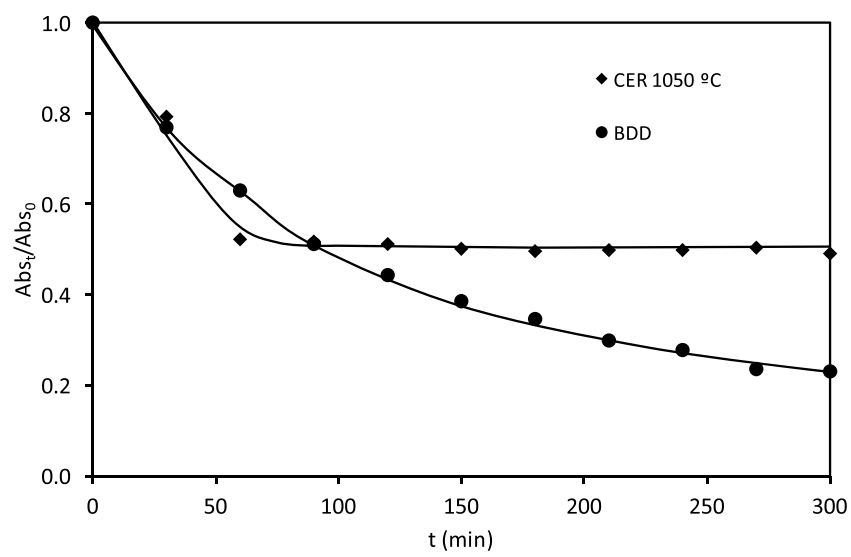

Figure 7. Evolution of the relative absorbance (at $310 \mathrm{~nm}$ ) with the electrolysis time for the electrochemical degradation of RB5 with the ceramic electrode sintered at $1050{ }^{\mathrm{a}} \mathrm{C}$ and the BDD electrode in the undivided reactor.

UV-visible absorption spectra of the $100 \mathrm{mg} \cdot \mathrm{L}^{-1} \mathrm{RB} 5$ solution at different electrolysis times are shown in Fig. 6a) for the BDD electrode and in Fig. 6b) for the ceramic electrode sintered at $1050^{\circ} \mathrm{C}$. Before the electrolysis, the spectra of RB5 shows five bands: one in the visible region (at $595 \mathrm{~nm})$ and others in the ultraviolet region $(229$, $254,310$ and $391 \mathrm{~nm})$. The peak at $595 \mathrm{~nm}$ is related to the chromophoric azo group $(-\mathrm{N}=\mathrm{N}-)$, while the peaks at 254 and $310 \mathrm{~nm}$ are associated with benzene and naphthalene rings ${ }^{11,19,58}$. As can be seen in Fig. 6a), all the peaks decrease as the electrolysis proceeded. The diminution of the peak at $595 \mathrm{~nm}$ suggests that the chromophore groups are broken down easily. On the other hand, the decrease in absorbance in the UV region is lower, and consequently, the aromatic structures remain more stable. This fact explains the low COD removal rate shown in Fig. 5.

For the ceramic electrode (Fig. 6b)), it was observed a progressive decrease of the absorption band at $595 \mathrm{~nm}$, along with a shift towards lower wavelengths (at $523 \mathrm{~nm}$ ). This was evidenced by a color change in the solution from the initial characteristic blue color of the RB5 solution to a final reddish color. Jager et al..$^{59}$ obtained an identical UV-Visible spectrum for RB5, as well as the same reddish color, that was attributed to the presence of an isoxazole derivative formed by the cyclization of the original molecule in the oxidation process. After $5 \mathrm{~h}$ of treatment, the absorbance in the UV region remained almost constant with time which suggests the persistence of aromatic rings.

In order to compare the discoloration rate $(595 \mathrm{~nm})$ shown in Fig. 4 and the aromatic fragment degradation $(310 \mathrm{~nm})$, the evolution with time of the relative absorbance measured at $310 \mathrm{~nm}$ for the ceramic electrode sintered at $1050^{\circ} \mathrm{C}$ and the BDD electrode is shown in Fig. 7 at $15 \mathrm{~mA} \cdot \mathrm{cm}^{-2}$. Comparing Figs. 4 and 7 , it is inferred that discoloration of RB5 is faster, while the degradation of benzenic or naphtalenic cycles is much more difficult. For the ceramic electrode, the band at $310 \mathrm{~nm}$ decreases rapidly reaching a plateau at $60 \mathrm{~min}$ and then remains constant with time, while for the BDD electrode this band decreases continuously with time, but at a lower rate than the band at $595 \mathrm{~nm}$. The observed differences between the ceramic electrodes and the BDD electrode in the absorption band at $310 \mathrm{~nm}$ would explain why the ceramic electrodes do not practically present COD removal, and why the discoloration of the BDD electrode is faster than the degradation of the benzenic or naphtalenic rings.

Therefore, in this type of reactor, the BDD anode is more efficient than the ceramic one as the BDD electrode reduced a $35 \%$ of the $\mathrm{COD}$, while the ceramic anodes were not active for COD removal. Using the BDD electrode the $\mathrm{N}=\mathrm{N}$ bonds of the azo groups are attacked first, causing discoloration unlike what happens in the ceramic electrode, in which the RB5 molecule undergoes an intramolecular cyclization causing changes in the bands of the UV-VIS spectra. The aromatic ring structures are more stable, and consequently, the COD removal is slower. On the other hand, it can be concluded that by-products formed with the ceramic electrode are more difficult to degrade and therefore a decrease in COD values is not observed.

Divided reactor. According to the previous results, it seems necessary to perform the electrochemical oxidation of the RB5 in a divided reactor. In this case, the RB5 solution was placed in the anodic chamber, and the use of a membrane between the compartments of the reactor is justified in order to prevent the reduction of the electrogenerated oxidizing species and the oxidized organic compounds. Electrolysis experiments were performed with the ceramic electrode sintered at $1050^{\circ} \mathrm{C}$ under three values of $\mathrm{i}\left(5,10\right.$ and $\left.15 \mathrm{~mA} \cdot \mathrm{cm}^{-2}\right)$.

The variation of the relative absorbance with time of a $100 \mathrm{mg} \cdot \mathrm{L}^{-1} \mathrm{RB} 5$ solution at 595 and $310 \mathrm{~nm}$ is presented in Figs. 8 and 9, respectively. Comparing both figures, it can be concluded that higher removal efficiency for RB5 was achieved at all applied current densities in the visible region. The discoloration at $595 \mathrm{~nm}$ after 90 min of electrolysis was $71 \%, 98 \%$ and $100 \%$ for 5,10 and $15 \mathrm{~mA} \cdot \mathrm{cm}^{-2}$ respectively. The disappearance of the absorption band of $595 \mathrm{~nm}$ beyond $90 \mathrm{~min}$ at the highest current density may be attributed to the action of the $\cdot \mathrm{OH}$ radicals.

However, as can be seen in Fig. 9, lower degradation efficiencies were obtained in the absorption band of $310 \mathrm{~nm}$, which indicates that the aromatic structures of the RB5 molecule are more stable towards electrochemical degradation. However, unlike what happened in the undivided reactor with the same ceramic electrodes, 


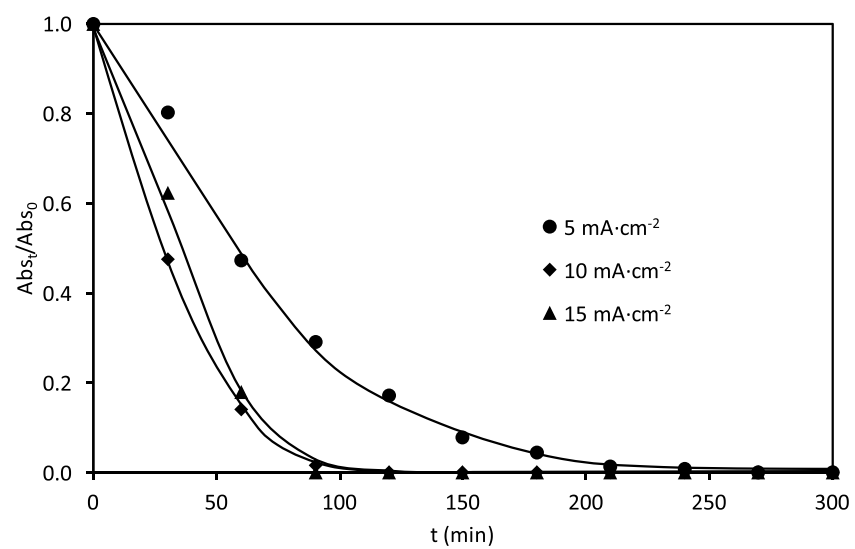

Figure 8. Effect of the applied current density on the evolution of the relative absorbance (at $595 \mathrm{~nm}$ ) with the electrolysis time for the electrochemical degradation of RB5 with the ceramic electrode sintered at $1050^{\circ} \mathrm{C}$ in the divided reactor.

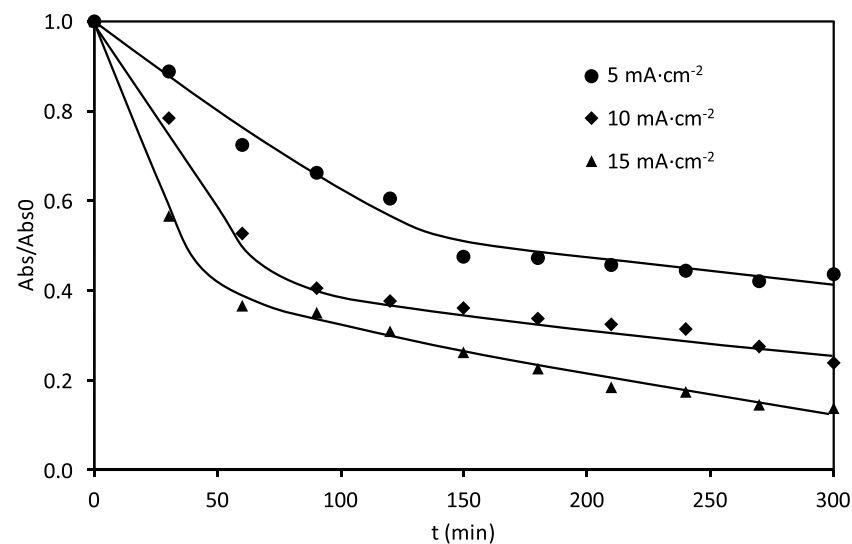

Figure 9. Effect of the applied current density on the evolution of the relative absorbance (at $310 \mathrm{~nm}$ ) with the electrolysis time for the electrochemical degradation of RB5 with the ceramic electrode sintered at $1050^{\circ} \mathrm{C}$ in the divided reactor.

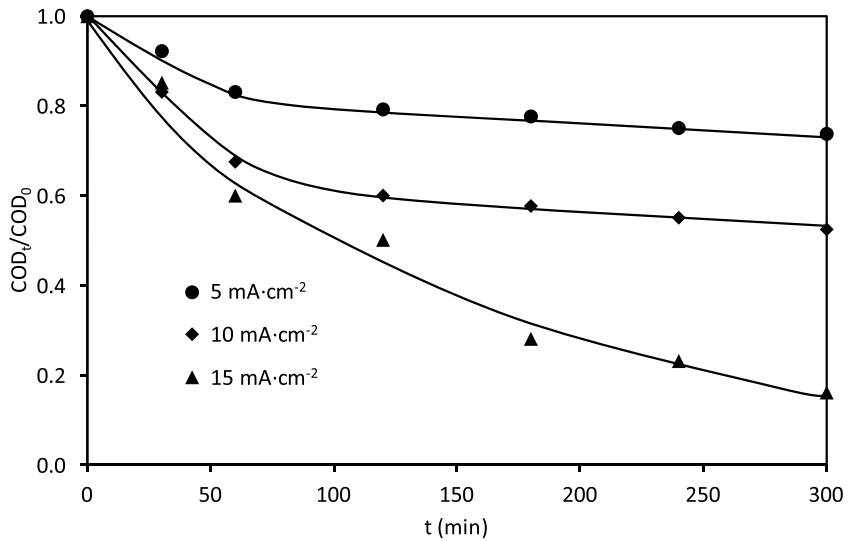

Figure 10. Effect of the applied current density on the evolution of the relative COD removal with the electrolysis time for the electrochemical degradation of RB5 with the ceramic electrode sintered at $1050^{\circ} \mathrm{C}$ in the divided reactor.

where the absorption band of $310 \mathrm{~nm}$ remained constant after 60 minutes of electrolysis (Fig. 7), in this case, the relative absorbance at $310 \mathrm{~nm}$ diminishes rapidly until 60 minutes of electrolysis, and then it continues decreasing more slowly. Comparing Figs. 8 and 9, it is inferred that the relative absorbance decreases more slowly at $310 \mathrm{~nm}$, 


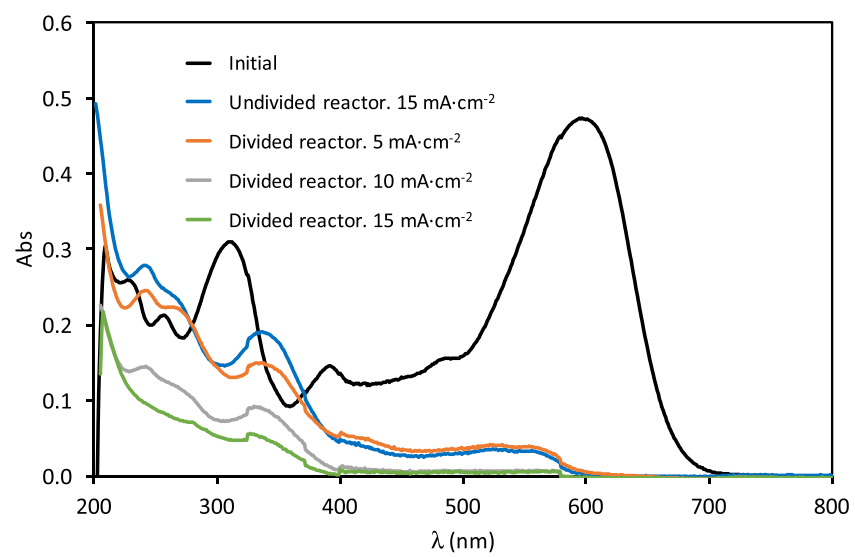

Figure 11. UV-visible absorption spectra of a $100 \mathrm{mg} \cdot \mathrm{L}^{-1} \mathrm{RB} 5$ solution during degradation with the ceramic electrode sintered at $1050^{\circ} \mathrm{C}$. Comparison of the divided and undivided reactors.

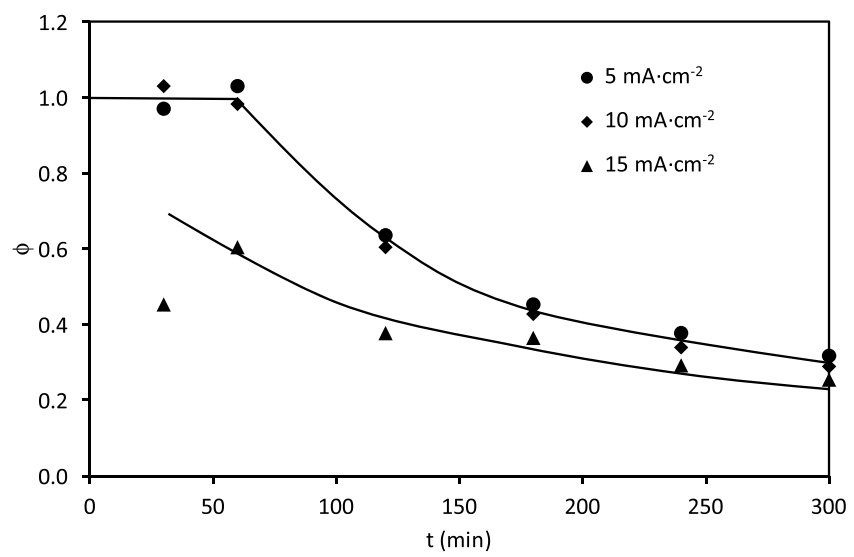

Figure 12. Effect of the applied current density on the evolution of $\mathrm{CE}$ with the electrolysis time for the electrochemical degradation of RB5 with the ceramic electrode sintered at $1050^{\circ} \mathrm{C}$ in the divided reactor.

which is reflected by a low mineralization degree of the dye. This fact can be verified in Fig. 10, which shows the evolution of the relative COD over time for the three applied current densities under study. In these experiments, a 30,50 and $80 \%$ of the COD removal was recorded at the end of the electrolysis at 5,10 and $15 \mathrm{~mA} \cdot \mathrm{cm}^{-2}$, respectively. The change in the COD removal follows a similar trend to that observed for the relative absorbance at $310 \mathrm{~nm}$ (Fig. 9). Similar differences between color and COD removal have been obtained by other authors when studying the degradation of dyes by electrocoagulation ${ }^{20,21}$, electrochemical oxidation ${ }^{30,60-65}$, photocatalysis ${ }^{9,11}$ photo-Fenton ${ }^{19,57}$ or biological methods ${ }^{13,66}$.

The oxidation of organic compounds on $\mathrm{SnO}_{2}-\mathrm{Sb}_{2} \mathrm{O}_{5}$ electrodes proceeds according to the following reaction $^{67-69}$ :

$$
\mathrm{SnO}_{2}+\mathrm{H}_{2} \mathrm{O} \rightarrow \mathrm{SnO}_{2}(\cdot \mathrm{OH})+\mathrm{H}^{+}+e^{-}
$$

$\mathrm{SnO}_{2}(\cdot \mathrm{OH})$ can react with the organic compounds (R) to produce $\mathrm{CO}_{2}, \mathrm{H}_{2} \mathrm{O}$, etc. though reaction (4) or be further oxidized to generate $\mathrm{O}_{2}$ gas through reaction (5):

$$
\begin{gathered}
\mathrm{SnO}_{2}(\cdot \mathrm{OH})+R \rightarrow \mathrm{SnO}_{2}+m \mathrm{CO}_{2}+n \mathrm{H}_{2} \mathrm{O}+\mathrm{H}^{+}+e^{-} \\
\mathrm{SnO}_{2}(\cdot \mathrm{OH}) \rightarrow \mathrm{SnO}_{2}+\frac{1}{2} \mathrm{O}_{2}+\mathrm{H}^{+}+e^{-}
\end{gathered}
$$

UV-visible absorption spectra of a $100 \mathrm{mg} \cdot \mathrm{L}^{-1} \mathrm{RB} 5$ solution before and after the treatment at the three applied current densities under study are presented in Fig. 11, and are compared with the spectra obtained in the undivided reactor at $15 \mathrm{~mA} \cdot \mathrm{cm}^{-2}$. Before the treatment, UV-visible spectra of RB5 show the characteristic absorption bands commented previously. When the solution was treated in the divided reactor, the absorption peak present at $595 \mathrm{~nm}$ disappears. Besides, the UV band at $310 \mathrm{~nm}$ decreased, although at a slower rate. During the treatment of the RB5 solution in the divided reactor, the absorbance values diminished all over the spectral window, unlike what happens in the undivided reactor. 
The evolution of the current efficiency $(\phi)$ with time, calculated from Eq. (2), is presented in Fig. 12 for the electrolysis of a $100 \mathrm{mg} \cdot \mathrm{L}^{-1} \mathrm{RB} 5$ solution. At 5 and $10 \mathrm{~mA} \cdot \mathrm{cm}^{-2}$, $\phi$ values of $100 \%$ were obtained during the first hour of electrolysis, although low efficiencies in the degradation of the COD were obtained in this period of time (Fig. 10). For these i values, after the first hour of electrolysis, $\phi$ decreased exponentially with time until reaching values close to $30 \%$. However, at $15 \mathrm{~mA} \cdot \mathrm{cm}^{-2}$, $\phi$ decreased exponentially with time from the beginning of the electrolysis experiments, and the values of $\phi$ achieved were lower than those obtained at 5 and $10 \mathrm{~mA} \cdot \mathrm{cm}^{-2}$ for every time, even though a greater efficiency in COD removal was obtained at this higher applied current density.

According to the literature ${ }^{26}$, hydroxyl radicals are the intermediates for reactions (4) and (5), oxidation of organic matter and the side oxygen evolution reaction, respectively. If the mineralization process is controlled by the transport of the pollutant from the solution to the anode, two situations can be distinguished. When $\mathrm{i}$ is lower than the limiting current value corresponding to the initial concentration of organic compounds, the electrolysis is carried out under current limited control, and high $\phi$ values can be reached, close to $100 \%$, at the beginning of the electrolysis. These $\phi$ values are maintained until the electrolysis is under mass transport control, which occurs at about 60 minutes of electrolysis for i values of 5 and $10 \mathrm{~mA} \cdot \mathrm{cm}^{-2}$. After 60 minutes of electrolysis, $\phi$ decreases with time. On the other hand, when $i$ is higher than the limiting current density from the beginning of the electrolysis, the electrolysis is mass-transport controlled, $\phi$ is always less than $100 \%$, and decreases with time, as it is seen in Fig. 12 at $15 \mathrm{~mA} \cdot \mathrm{cm}^{-2}$.

The maximum $\phi$ was always reached at the beginning of the electrochemical process (high COD concentrations), then it decreases as the initial COD does. The progressive decay of $\phi$ can be due to the production of oxidation intermediates difficult to destroy by hydroxyl radicals ${ }^{70}$. Besides, side reactions like oxygen evolution (Eq. 5) and the generation of other oxidants as $\mathrm{S}_{2} \mathrm{O}_{8}=$ from the supporting electrolyte would be favored at higher i values which contribute to the decrease of $\phi$ with the applied current density observed in Fig. $12^{71}$.

\section{Conclusions}

Mineralization of $\mathrm{RB} 5$ with Sb-doped $\mathrm{SnO}_{2}$ ceramic electrodes in divided and undivided electrochemical reactors has been studied in the present work. In the undivided reactor, high discoloration rates were reached at $595 \mathrm{~nm}$ with ceramic electrodes, but new bands appeared indicating the formation of an isoxazole derivative formed by the cyclization of the RB5 molecule in the oxidation process. This fact was not observed for the BDD electrode, which although showed lower efficiency in terms of color removal, led to a $35 \%$ of the COD removal at the same electrolysis time.

In the divided reactor, the reduction of the oxidized compounds formed was prevented by the presence of a membrane between the anodic and cathodic compartments. With this reactor configuration, although it was possible the discoloration of the solution while decreasing the COD, the COD degradation was slower than the discoloration rate. Moreover, although the RB5 degradation rate increased with i, the current efficiency decreased with this parameter.

Received: 2 October 2019; Accepted: 18 February 2020;

Published online: 11 March 2020

\section{References}

1. Daneshvar, N., Oladegaragoze, A. \& Djafarzadeh, N. Decolorization of basic dye solutions by electrocoagulation: An investigation of the effect of operational parameters. J. Hazard. Mater. 129, 116-122 (2006).

2. Şengil, I. A. \& Özacar, M. The decolorization of C.I. Reactive Black 5 in aqueous solution by electrocoagulation using sacrificial iron electrodes. J. Hazard. Mater. 161, 1369-1376 (2009).

3. Bandala, E. R. et al. Photocatalytic decolourisation of synthetic and real textile wastewater containing benzidine-based azo dyes. Chem. Eng. Process. Process Intensif. 47, 169-176 (2008).

4. Ahmad, A. L. \& Puasa, S. W. Reactive dyes decolourization from an aqueous solution by combined coagulation/micellar-enhanced ultrafiltration process. Chem. Eng. J. 132, 257-265 (2007).

5. Koyuncu, I. \& Topacik, D. Effects of operating conditions on the salt rejection of nanofiltration membranes in reactive dye/salt mixtures. Sep. Purif. Technol. 33, 283-294 (2003).

6. Damodar, R. A., You, S. J. \& Chou, H. H. Study the self cleaning, antibacterial and photocatalytic properties of $\mathrm{TiO}_{2}$ entrapped PVDF membranes. J. Hazard. Mater. 172, 1321-1328 (2009).

7. Srivastava, H. P., Arthanareeswaran, G., Anantharaman, N. \& Starov, V. M. Performance of modified poly(vinylidene fluoride) membrane for textile wastewater ultrafiltration. Desalination 282, 87-94 (2011).

8. Mook, W. T., Ajeel, M. A., Aroua, M. K. \& Szlachta, M. The application of iron mesh double layer as anode for the electrochemical treatment of Reactive Black 5 dye. J. Environ. Sci. (China) 54, 184-195 (2017).

9. Tang, C. \& Chen, V. The photocatalytic degradation of reactive black 5 using $\mathrm{TiO}_{2} / \mathrm{UV}$ in an annular photoreactor. Water Res. 38, 2775-2781 (2004).

10. Aguedach, A., Brosillon, S., Morvan, J. \& Lhadi, E. K. Photocatalytic degradation of azo-dyes reactive black 5 and reactive yellow 145 in water over a newly deposited titanium dioxide. Appl. Catal. B Environ. 57, 55-62 (2005).

11. Sahel, K. et al. Photocatalytic decolorization of Remazol Black 5 (RB5) and Procion Red MX-5B-Isotherm of adsorption, kinetic of decolorization and mineralization. Appl. Catal. B Environ. 77, 100-109 (2007).

12. Işik, M. \& Sponza, D. T. A batch kinetic study on decolorization and inhibition of Reactive Black 5 and Direct Brown 2 in an anaerobic mixed culture. Chemosphere 55, 119-128 (2004).

13. El Bouraie, M. \& El Din, W. S. Biodegradation of Reactive Black 5 by Aeromonas hydrophila strain isolated from dye-contaminated textile wastewater. Sustain. Environ. Res. 26, 209-216 (2016).

14. Meriç, S., Kaptan, D. \& Ölmez, T. Color and COD removal from wastewater containing Reactive Black 5 using Fenton's oxidation process. Chemosphere 54, 435-441 (2004).

15. Dojčinović, B. P. et al. Decolorization of Reactive Black 5 using a Dielectric Barrier Discharge in the presence of inorganic salts. J. Serbian Chem. Soc. 77, 535-548 (2012).

16. Cerón-Rivera, M., Dávila-Jiménez, M. M. \& Elizalde-González, M. P. Degradation of the textile dyes Basic yellow 28 and Reactive black 5 using diamond and metal alloys electrodes. Chemosphere 55, 1-10 (2004). 
17. Yavuz, Y. \& Shahbazi, R. Anodic oxidation of Reactive Black 5 dye using boron doped diamond anodes in a bipolar trickle tower reactor. Sep. Purif. Technol. 85, 130-136 (2012).

18. Vasconcelos, V. M., Ponce-De-León, C., Nava, J. L. \& Lanza, M. R. V. Electrochemical degradation of RB-5 dye by anodic oxidation, electro-Fenton and by combining anodic oxidation-electro-Fenton in a filter-press flow cell. J. Electroanal. Chem. 765, 179-187 (2016).

19. Lucas, M. S. \& Peres, J. A. Decolorization of the azo dye Reactive Black 5 by Fenton and photo-Fenton oxidation. Dye. Pigment. 71, $236-244$ (2006).

20. Song, S., He, Z., Qiu, J., Xu, L. \& Chen, J. Ozone assisted electrocoagulation for decolorization of C.I. Reactive Black 5 in aqueous solution: An investigation of the effect of operational parameters. Sep. Purif. Technol. 55, 238-245 (2007).

21. Chang, S. H. et al. Treatment of Reactive Black 5 by combined electrocoagulation-granular activated carbon adsorption-microwave regeneration process. J. Hazard. Mater. 175, 850-857 (2010).

22. Daneshvar, N., Salari, D. \& Khataee, A. R. Photocatalytic degradation of azo dye acid red 14 in water: investigation of the effect of operational parameters. J. Photochem. Photobiol. A Chem. 157, 111-116 (2003).

23. Panizza, M. \& Cerisola, G. Electrocatalytic materials for the electrochemical oxidation of synthetic dyes. Appl. Catal. B Environ. 75, 95-101 (2007).

24. Martínez-Huitle, C. A. \& Brillas, E. Decontamination of wastewaters containing synthetic organic dyes by electrochemical methods: A general review. Appl. Catal. B Environ. 87, 105-145 (2009).

25. Panizza, M. \& Cerisola, G. Electro-Fenton degradation of synthetic dyes. Water Res. 43, 339-44 (2009).

26. Kapałka, A., Fóti, G. \& Comninellis, C. Kinetic modelling of the electrochemical mineralization of organic pollutants for wastewater treatment. J. Appl. Electrochem. 38, 7-16 (2008).

27. Panizza, M. \& Cerisola, G. Application of diamond electrodes to electrochemical processes. Electrochim. Acta 51, 191-199 (2005).

28. Panizza, M. \& Cerisola, G. Direct And Mediated Anodic Oxidation of Organic Pollutants. Chem. Rev. 109, 6541-6569 (2009).

29. Brillas, E. \& Martínez-Huitle, C. A. Decontamination of wastewaters containing synthetic organic dyes by electrochemical methods. An updated review. Appl. Catal. B Environ. 166-167, 603-643 (2015).

30. Aquino, J. M., Pereira, G. F., Rocha-Filho, R. C., Bocchi, N. \& Biaggio, S. R. Electrochemical degradation of a real textile effluent using boron-doped diamond or $\beta-\mathrm{PbO}_{2}$ as anode. J. Hazard. Mater. 192, 1275-1282 (2011).

31. Comninellis, C. \& Pulgarin, C. Electrochemical oxidation of phenol for wastewater treatment using $\mathrm{SnO}_{2}$ anodes. J. Appl. Electrochem. 23, 108-112 (1993).

32. Zanta, C. L. P. S., Michaud, P.-A., Comninellis, C., De Andrade, A. R. \& Boodts, J. F. C. Electrochemical oxidation of $p$-chlorophenol on $\mathrm{SnO}_{2}-\mathrm{Sb}_{2} \mathrm{O}_{5}$ based anodes for wastewater treatment. J. Appl. Electrochem. 33, 1211-1215 (2003).

33. Kötz, R., Stucki, S. \& Carcer, B. Electrochemical waste water treatment using high overvoltage anodes. Part I: Physical and electrochemical properties of $\mathrm{SnO}_{2}$ anodes. J. Appl. Electrochem. 21, 14-20 (1991).

34. Polcaro, A. M., Palmas, S., Renoldi, F. \& Mascia, M. On the performance of $\mathrm{Ti} / \mathrm{SnO}_{2}$ and $\mathrm{Ti} / \mathrm{PbO}_{2}$ anodesin electrochemical degradation of 2-chlorophenolfor wastewater treatment. J. Appl. Electrochem. 29, 147-151 (1999).

35. Martínez-Huitle, C. A. et al. Removal of the Pesticide Methamidophos from Aqueous Solutions by Electrooxidation using $\mathrm{Pb} / \mathrm{PbO}_{2}$, $\mathrm{Ti} / \mathrm{SnO}_{2}$, and Si/BDD Electrodes. Environ. Sci. Technol. 42, 6929-6935 (2008).

36. Watts, R. J., Wyeth, M. S., Finn, D. D. \& Teel, A. L. Optimization of Ti/ $\mathrm{SnO}_{2}-\mathrm{Sb}_{2} \mathrm{O}_{5}$ anode preparation for electrochemical oxidation of organic contaminants in water and wastewater. J. Appl. Electrochem. 38, 31-37 (2007).

37. Zhuo, Q., Deng, S., Yang, B., Huang, J. \& Yu, G. Efficient Electrochemical Oxidation of Perfluorooctanoate Using a Ti/SnO $2-S b-B i$ Anode. Environ. Sci. Technol. 45, 2973-2979 (2011).

38. Lipp, L. \& Pletcher, D. The preparation and characterization of tin dioxide coated titanium electrodes. Hecrrochimico Acta 42, 1091-1099 (1997).

39. Zuca, S., Terzi, M., Zaharescu, M. \& Matiasovsky, K. Contribution to the study of $\mathrm{SnO}_{2}$-based ceramics. J. Mater. Sci. 26, 1673-1676 (1991).

40. Park, S.-Y., Mho, S.-I., Chi, E. O., Kwon, Y. U. \& Park, H. L. Characteristics of Pt thin films on the conducting ceramics TiO and Ebonex $\left(\mathrm{Ti}_{4} \mathrm{O}_{7}\right)$ as electrode materials. Thin Solid Films 258, 5-9 (1995).

41. Chen, G., Betterton, E. A. \& Arnold, R. G. Electrolytic oxidation of trichloroethylene using a ceramic anode. J. Appl. Electrochem. 29, 961-970 (1999).

42. Scialdone, O., Galia, A. \& Filardo, G. Electrochemical incineration of 1,2-dichloroethane: Effect of the electrode material. Electrochim. Acta 53, 7220-7225 (2008).

43. Bejan, D., Malcolm, J. D., Morrison, L. \& Bunce, N. J. Mechanistic investigation of the conductive ceramic Ebonex ${ }^{\circledR}$ as an anode material. Electrochim. Acta 54, 5548-5556 (2009).

44. Zaky, A. M. \& Chaplin, B. P. Porous substoichiometric $\mathrm{TiO}_{2}$ anodes as reactive electrochemical membranes for water treatment. Environ. Sci. Technol. 47, 6554-6563 (2013).

45. Zhang, C. et al. Three-dimensional electrochemical process for wastewater treatment: A general review. Chem. Eng. J. 228, 455-467 (2013).

46. Mora-Gómez, J. et al. Evaluation of new ceramic electrodes based on Sb-doped $\mathrm{SnO}_{2}$ for the removal of emerging compounds present in wastewater. Ceram. Int. 44, 2216-2222 (2018).

47. Mora-Gómez, J., Ortega, E., Mestre, S., Pérez-Herranz, V. \& García-Gabaldón, M. Electrochemical degradation of norfloxacin using $\mathrm{BDD}$ and new Sb-doped $\mathrm{SnO}_{2}$ ceramic anodes in an electrochemical reactor in the presence and absence of a cation-exchange membrane. Sep. Purif. Technol. 208, 68-75 (2019).

48. Montilla, F., Morallón, E., De Battisti, A. \& Vázquez, J. L. Preparation and Characterization of Antimony-Doped Tin Dioxide Electrodes. Part 1. Electrochemical Characterization. J. Phys. Chem. B 108, 5036-5043 (2004).

49. Zhang, L., Xu, L., He, J. \& Zhang, J. Preparation of Ti//SnO 2 -Sb electrodes modified by carbon nanotube for anodic oxidation of dye wastewater and combination with nanofiltration. Electrochim. Acta 117, 192-201 (2014).

50. Martínez-Huitle, C. A., dos Santos, E. V., de Araújo, D. M. \& Panizza, M. Applicability of diamond electrode/anode to the electrochemical treatment of a real textile effluent. J. Electroanal. Chem. 674, 103-107 (2012).

51. Correa-Lozano, B., Comninellis, C. \& De Battisti, A. Service life of $\mathrm{Ti}^{\prime} \mathrm{SnO}_{2}-\mathrm{Sb}_{2} \mathrm{O}_{5}$ anodes. J. Appl. Electrochem. 27, 970-974 (1997).

52. Loge, F. J., Inouye, T. \& Watts, R. J. Disinfection of Secondary Effluents Using Tin Oxide Anodes. Water Environ. Res. 78, 41-48 (2006).

53. Wu, W., Huang, Z.-H., Hu, Z.-T., He, C. \& Lim, T.-T. High performance duplex-structured $\mathrm{SnO}_{2}$-Sb-CNT composite anode for bisphenol A removal. Sep. Purif. Technol. 179, 25-35 (2017).

54. Ding, H. yang, Feng, Y. jie \& Liu, J. feng. Preparation and properties of $\mathrm{Ti} / \mathrm{SnO}_{2}-\mathrm{Sb}_{2} \mathrm{O}_{5}$ electrodes by electrodeposition. Mater. Lett. 61, 4920-4923 (2007).

55. Chen, A. \& Nigro, S. Influence of a Nanoscale Gold Thin Layer on $\mathrm{Ti} / \mathrm{SnO}_{2}-\mathrm{Sb}_{2} \mathrm{O}_{5}$ Electrodes. J. Phys. Chem. B 107, 13341-13348 (2003).

56. Kang, S. F., Liao, C. H. \& Hung, H. P. Peroxidation treatment of dye manufacturing wastewater in the presence of ultraviolet light and ferrous ions. J. Hazard. Mater. 65, 317-333 (1999).

57. Feng, J., Hu, X., Yue, P. L., Zhu, H. Y. \& Lu, G. Q. Discoloration and mineralization of Reactive Red HE-3B by heterogeneous photoFenton reaction. Water Res. 37, 3776-3784 (2003). 
58. Méndez-Martínez, A. J. et al. Electrochemical reduction and oxidation pathways for Reactive Black 5 dye using nickel electrodes in divided and undivided cells. Electrochim. Acta 59, 140-149 (2012).

59. Jager, D., Kupka, D., Vaclavikova, M., Ivanicova, L. \& Gallios, G. Degradation of Reactive Black 5 by electrochemical oxidation. Chemosphere 190, 405-416 (2018).

60. Chen, X., Chen, G. \& Yue, P. L. Anodic oxidation of dyes at novel Ti/B-diamond electrodes. Chem. Eng. Sci. 58, 995-1001 (2003).

61. El-Ghenymy, A. et al. Decolorization and mineralization of Orange $\mathrm{G}$ azo dye solutions by anodic oxidation with a boron-doped diamond anode in divided and undivided tank reactors. Electrochim. Acta 130, 568-576 (2014).

62. Guenfoud, F., Mokhtari, M. \& Akrout, H. Electrochemical degradation of malachite green with BDD electrodes: Effect of electrochemical parameters. Diam. Relat. Mater. 46, 8-14 (2014).

63. Koparal, A. S., Yavuz, Y., Gürel, C. \& Öğütveren, Ü. B. Electrochemical degradation and toxicity reduction of C.I. Basic Red 29 solution and textile wastewater by using diamond anode. J. Hazard. Mater. 145, 100-108 (2007).

64. Panakoulias, T., Kalatzis, P., Kalderis, D. \& Katsaounis, A. Electrochemical degradation of Reactive Red 120 using DSA and BDD anodes. J. Appl. Electrochem. 40, 1759-1765 (2010).

65. Vasconcelos, V. M. et al. Electrochemical removal of Reactive Black 5 azo dye using non-commercial boron-doped diamond film anodes. Electrochim. Acta 178, 484-493 (2015).

66. García-Montaño, J., Domènech, X., García-Hortal, J. A., Torrades, F. \& Peral, J. The testing of several biological and chemical coupled treatments for Cibacron Red FN-R azo dye removal. J. Hazard. Mater. 154, 484-490 (2008).

67. Correa-Lozano, B., Comninellis, C. \& De Battisti, A. Electrochemical properties of $\mathrm{Ti}^{2} / \mathrm{SnO}_{2}-\mathrm{Sb}_{2} \mathrm{O}_{5}$ electrodes prepared by the spray pyrolysis technique. J. Appl. Electrochem. 26, 683-688 (1996).

68. Marselli, B., Garcia-Gomez, J., Michaud, P.-A., Rodrigo, M. A. \& Comninellis, C. Electrogeneration of Hydroxyl Radicals on BoronDoped Diamond Electrodes. J. Electrochem. Soc. 150, D79-D83 (2003).

69. Chen, X., Gao, F. \& Chen, G. Comparison of Ti/BDD and Ti/ $\mathrm{SnO}_{2}-\mathrm{Sb}_{2} \mathrm{O}_{5}$ electrodes for pollutant oxidation. J. Appl. Electrochem. 35, 185-191 (2005).

70. Guinea, E. et al. Degradation of the fluoroquinolone enrofloxacin by electrochemical advanced oxidation processes based on hydrogen peroxide electrogeneration. Electrochim. Acta 55, 2101-2115 (2010).

71. Sirés, I., Brillas, E., Oturan, M. A., Rodrigo, M. A. \& Panizza, M. Electrochemical advanced oxidation processes: today and tomorrow. A review. Environ. Sci. Pollut. Res. Int. 21, 8336-8367 (2014).

\section{Acknowledgements}

The authors thank the financial support from the Ministerio de Economía y Competitividad (Spain) under projects CTQ2015-65202-C2-1-R and RTI2018-101341-B-C21, co-financed with FEDER funds.

\section{Author contributions}

T.D. and J.M.G. carried out the experimental work of the manuscript (analytical COD and UV-Vis measurements and electrolysis experiments). E.O. and M.G.G. supervised the experimental work. S.M. manufactured the ceramic employed in this work. V.P.H wrote the main manuscript text and G.C. reviewed the whole manuscript.

\section{Competing interests}

The authors declare no competing interests.

\section{Additional information}

Correspondence and requests for materials should be addressed to M.G.-G.

Reprints and permissions information is available at www.nature.com/reprints.

Publisher's note Springer Nature remains neutral with regard to jurisdictional claims in published maps and institutional affiliations.

(c) (i) Open Access This article is licensed under a Creative Commons Attribution 4.0 International

License, which permits use, sharing, adaptation, distribution and reproduction in any medium or format, as long as you give appropriate credit to the original author(s) and the source, provide a link to the Creative Commons license, and indicate if changes were made. The images or other third party material in this article are included in the article's Creative Commons license, unless indicated otherwise in a credit line to the material. If material is not included in the article's Creative Commons license and your intended use is not permitted by statutory regulation or exceeds the permitted use, you will need to obtain permission directly from the copyright holder. To view a copy of this license, visit http://creativecommons.org/licenses/by/4.0/.

(c) The Author(s) 2020 